\title{
Trade on the North Eastern Bank of the Lagos Lagoon: A Focus on Ejinrin Lagoon Market, 1851-1939
}

\author{
Oladipo O. Olubomehin \\ Olabisi Onabanjo University, Nigeria \\ olubomehind@yahoo.com; olubomehind@gmail.com
}

\begin{abstract}
This article discusses trade and market activities on the north eastern bank of the Lagos Lagoon. Our particular focus is on the ljebu lagoon market of Ejinrin. During the period covered by this study, Ejinrin was a meeting point for traders from Lagos and those from southeastern Yoruba hinterland. Traders reportedly attended the market not only from ljebuland but also from places such as Gbongan, Ile-Ife, llesha, Oyo, Ilorin, Okitipupa, Owo, Epe, Orimedu, Atijere and other towns in Yorubaland. Colonial records show that attendance at Ejinrin reached between 20,000 and 26,000 on a market day by the end of the nineteenth century and by 1908 , the market was rated as the largest market in the whole of the western provinces of Nigeria. Such was the strategic importance of this market that it supplied Lagos with the bulk of the palm oil shipped overseas during the pre-colonial and colonial periods. Thus, the lagoon market occupied a very important place in the local economy of the ljebu and that of Lagos. This article is an attempt to understand this aspect of the indigenous economy of Nigeria. It is an attempt to analyze and document the history of commercial activities in this geographical zone of the Lagos (ljebu) Lagoon. The study relied largely on documentary evidence got from the National Archives, Ibadan and extensive oral evidence collected from those who, at one time or the other, had attended the market.
\end{abstract}




\section{Introduction}

Ejinrin is located in present Lagos State. ${ }^{1}$ It is situated at about twenty-five kilometers to the south of Ijebu-Ode on the northern bank of the Lagos Lagoon. It lies between the Ibu and Owo rivers in what is still called Epe 'District'. It is bounded in the north by the land of Odekuku, in the south by the Lagos Lagoon, in the east by the Owo River and in the west by the Arogbo-Lumodo swamp. ${ }^{2}$ Ejinrin market, which is the focus in this article, is located on the north eastern bank of the Lagos Lagoon, forming a strategic link between Lagos and the rest of southeastern Yoruba hinterland. Its location by the lagoon provided water transportation linkage with her neighbors. It also provided avenue for fishing which was the occupation of many people in Ejinrin and the lagoon area.

The purpose of this article is to provide knowledge on an aspect of Yoruba and indeed, Nigerian economic history on which not much is yet known port and market history which is an integral part of the history economic activities along the Lagos (Ijebu) lagoon. As anywhere, ports and markets along the lagoon functioned as gateway for the economies of the societies which they served. They were an avenue through which goods and services entered into, and ultimately got distributed within the society. They therefore acted as vehicles of economic development within the society.

Ejinrin market played an important role not only in the Yoruba traditional economy but also in the economy of the communities located both along, and on the Lagos Lagoon. Our focus on Ejinrin is borne out of the fact that much of the trading activities on the Lagos Lagoon took place in the port and market. Indeed, Ejinrin was a center of economic activities for traders from Lagos and the hinterland during the period of study. Traders also came to the market from Gbongan, Ile-Ife, Ilesha, Oyo, Ilorin, Okitipupa, Owo, Epe and other towns in Yorubaland. ${ }^{3}$ Therefore, a study of the Ejinrin market, constitutes an important aspect of the study of indigenous economy of the Yoruba.

By its location on the Lagos Lagoon, Ejinrin strategically connected Lagos with the southeast Yoruba hinterland. From Ejinrin, European manufactured goods and other commodities were distributed to different parts of Yorubaland. Not only this, Ejinrin supplied Lagos with the bulk of the produce

1. Ade Adefuye, B. A. Agiri and Jide Osuntokun, eds., History of the Peoples of Lagos State (Lagos: Lantern Books, 1987), 7.

2. National Archives Ibadan (hereafter N.A.I.): Ije Prof 6, File J. 37/1924: Ejinrin Land case, 6 .

3. Afolabi Ojo, Yoruba Culture (Ile Ife: Unife Press, 1966), 50; Chief S.B. Akintola, interviewed at Ejnirin, April 1988 and Mrs. Moriamo Gbadamosi, 50+ years, Iyaloja, Ejinrin market, interviewed on 29 April 1988. 
shipped overseas during the pre-colonial and colonial periods. In 1853 alone, Ejinrin supplied Lagos with between 60,000 and 70,000 gallons of palm oil. ${ }^{4}$ This pattern continued into the colonial era. Indeed, the advent of colonial rule boosted the fortunes of the market. In 1895, only three years after the formal inauguration of colonial rule in Ijebuland, Ejinrin market reportedly had an attendance of 20,000 to 26,000 persons on each market day. ${ }^{5}$ This article looks at trading and marketing activities along the lagoon with a special focus on developments in Ejinrin port and market in the period between 1851 and 1939.

\section{The Rise of Ejinrin Lagoon Port and Market}

A number of factors explain the centrality of Ejinrin as a commercial center on the Lagos Lagoon. We will just examine a few of these factors. A central factor was the strategic geographical location of Ejinrin by a navigable waterway - the lagoon. The lagoon linked Ejinrin market to the large Lagos population. Not only this, Ejinrin was a meeting point for hinterland traders wishing to trade with Lagos merchants. Lagos, an urban center, could not produce the foodstuffs required for consumption by its population because of its location on poor sandy soil. It therefore relied on the Yoruba hinterland for the supply of basic food items. It was in this regard that Ejinrin market became a center where Lagos traders met others from the hinterland for the exchange of goods. Trade and market activities in Ejinrin were enhanced by the presence of the Ijebu, who were middlemen, and who took advantage of the opportunity created by the location of Ejinrin to dominate commercial affairs in the market.

The lagoon made Ejinrin market accessible to traders from Ondo, Epe, Okitipupa, Atijere and the Ijebu waterside settlements of Abigi and Iwopin. Indeed, the importance of a lagoon location in the pre-colonial economy of Nigeria cannot be over-emphasized. A lagoon side market like Ejinrin acted as a meeting point for the lagoon and upland settlements where goods and services were exchanged and distributed. There is no gainsaying that before the introduction of motor vehicles, travel on the lagoons was far easier than movement on the trade routes through the forest. Thus, from the very beginning, the lagoon played a vital role in the growth of trade not only in Ejinrin but along the stretch of the Lagos coastal area. Besides the lagoon, there existed a

4. A.L. Mabogunje, Urbanisation in Nigeria (London: University of London Press, 1968), 245.

5. National Archives Ibadan [NAI]: CSO 1/1, 15 Dispatches to Secretary of State Nos. 1 to 246 . 2nd Jan-31st December, 1895, 110. 
network of creeks and rivers which connected Ejinrin with the Ijebu mainland. Some of these rivers were Ona, Osun and Yemoji rivers.

Another factor which contributed to the growth of trade in Ejinrin was fish trade. The lagoon created opportunities for fishing. Indeed, one of the occupations of the people in Ejinrin and the lagoon communities was fishing. Fishing in the area was done by the Ijo and Ilaje. They undertook extensive fishing on the lagoon. As Ejinrin gradually developed as a market, traders brought fish to the market from the neighboring lagoon side settlements of Oriba, Agbowa-Ikosi, Epe, Araromi, Ijede and Itoikin. The traders returned home with other articles which they bought in Ejinrin market. Different varieties of fish were brought to in Ejinrin market. They included sawa (sardinella aurita), aro (clarias genriepinus), obokun (chrysichtys nigrodigitatus), epiya (tilapia), kuta (sphyraena piscatorum), efolo (ethmalosa fimbniata), igbakere (lutjanus goreensis) and owere (trachinotus goreensis). ${ }^{6}$ There were fresh fish as well as smoked ones. But Ejinrin market tended to excel in the sale of dried fish.

Two more related factors contributed to the rise Ejinrin and by extension the growth of trade along the Lagos coastal area. The first was Kosoko's stay in Epe while the second were the nineteenth century Yoruba civil wars. In 1851, a dynastic struggle led to the expulsion of Kosoko from Lagos by the British. Subsequently, with the permission of the Awujale, he came to Epe with "some 400 or 300 warriors and several outstanding men" and settled there. ${ }^{7}$ Prior to his reign in Lagos between 1845 and 1851, Kosoko had stayed in Whydah where he was involved in the slave trade. When he came to Epe, "he engaged in the export trade presumably mainly in slaves but also in palm oil and other products from Ijebu". Ejinrin profited from Kosoko's trading activity.

The contribution of Kosoko to the growth of trade in the Ejinrin and Lagos area is evident in his activities in the lagoon area. Kosoko dominated commercial activity in Ejinrin and other lagoon markets of Itoikin and Ikorodu. ${ }^{9}$ It was because of the strategic position of Ejinrin for Kosoko's lagoon trade that he stationed his "Prime Minister", Oshodi Tapa, there. ${ }^{10}$ Kosoko collected such

6. I am grateful to Mr. Olukayode Olufosoye, a postgraduate student in the Department of Fishery, University of Ibadan, for supplying the zoological names of the fish. I wish also to thank Mr. (now Dr.) Sola Womiloju for the same purpose.

7. Robert Smith, "To the Palaver Islands: War and Diplomacy on the Lagos Lagoon in 1852-1854" Journal of the Historical Society of Nigeria, V.1 (1969): 7. The number of Kosoko's followers steadily increased to 1,500 people.

8. Robert Smith, "To the Palaver Islands".

9. Robert Smith, The Lagos Consulate 1851-1861, (London: Macmillan Press, 1978), 94.

10. G.O. Oguntomisin, "New forms of Political organization in Yorubaland in the mid-nineteenth century: A Comparative Study of Kurunmi's Ijaye and Kosoko's Epe" (Ph.D Thesis, University of Ibadan 1979), 228. 
articles as guns, ammunition, rum, cloths and tobacco from the Europeans. He distributed them to his followers who bartered them for palm oil in Ejinrin and other lagoon markets. ${ }^{11}$ Palm produce was thereafter taken from Ejinrin in canoes to Kosoko's ports at Lekki and Orimedu for sale to European merchants. ${ }^{12}$ Besides palm produce, Kosoko also traded in slaves. The slaves were procured from Ejinrin and other Ijebu markets. ${ }^{13}$ These he sold to the Portuguese and Brazilian slave dealers who clandestinely engaged in the slave trade. Ejinrin therefore, profited from Kosoko's trading activity.

Although between 1852 and 1854, Kosoko blockaded Lagos and nearly brought its economy to a standstill, ${ }^{14}$ appreciable trade still went on between Ejinrin and Lagos during the period. For instance, in 1853 while the blockade was on, Ejinrin supplied Lagos with 60,000 to 70,000 gallons of palm oil. ${ }^{15}$ The fact that such quantity of palm oil reached Lagos from Ejinrin market at a time when Kosoko was actively involved in piracy on the lagoon suggests that in spite of Kosoko's vigilance some trade was still done with Lagos. Although Kosoko returned to Lagos in 1862, the impact of his activities in Ejinrin and the lagoon area remained. The port and market had become prominent. Such was the growing importance of the market that McCoskry could say that "up to 1865 a great proportion of the palm oil brought to Lagos came from the banks of the lagoon from towns such as Ikorodu, Epe and Ejinrin market". ${ }^{16}$ It is true that the dearth of statistical data does not allow us to show the exact contribution of Kosoko to the growth of Ejinrin port and market. But from the aforementioned, there can be no doubt that Ejinrin benefitted from Kosoko's stay in Epe.

The nineteenth century Yoruba civil wars also contributed to the rise and growth of Ejinrin market. One striking implication of the wars for the growth of Ejinrin was that they provided the market with slaves which were demanded by the Portuguese and Brazilians who clandestinely engaged in the slave trade. ${ }^{17}$ The Lagos Lagoon on which Ejinrin market was located provided good

11. Ibid.

12. Ibid., 233.

13. Ibid., 233.

14. A. L. Mabogunje, Urbanization in Nigeria (London: University of London Press, 1968), 245.

15. A.L. Mabogunje, Urbanisation in Nigeria (London: University of London Press, 1968), 245.

16. Report of the Select Committee on Africa, 1865, 73, as cited in Mabogunje, Ibid., 245.

17. Though by 1851 an end had been put to the Brazilian slave trade, the increasing demand in Europe and elsewhere for sugar and cotton led to a revival of slave exports to Cuba and also an increased export to the southern U.S.A. Abolition of slave trade by the 
hiding places for ships evading the British men-of-war, ${ }^{18}$ a situation which contributed to its rise and growth.

European efforts at promoting "legitimate" trade also contributed to the growth of Ejinrin as a commercial center. After the abolition of slave trade, the Europeans needed oil to lubricate their manufacturing machines and to manufacture soap. ${ }^{19}$ The promotion of "legitimate" trade, therefore, created demands in Lagos which Ejinrin market tried to meet. While opposition to the slave trade was actively pursued, Europeans encouraged the indigenous people to take to commodity commerce. This effort yielded such dividends that by 1861, Lagos had witnessed an influx of some American and European merchants who came to have a share in the lucrative Lagos commerce and the trade in palm produce which enjoyed an increasing demand in Europe. ${ }^{20}$ But the trade in Lagos depended not only on European demands but also on the supply of palm produce from the hinterland. The Ijebu played an important middlemen role in the palm oil trade. Ejinrin market was a gateway through which palm produce got to Lagos. Ejinrin supplied Lagos with a substantial part of the palm oil shipped overseas in the 1850s. Three-quarters of the palm oil shipped in Lagos were products of Ijebu markets of Ejinrin and Ikorodu. ${ }^{21}$ Indeed, as Ayantuga points out, by 1855, the markets of Ikorodu and Ejinrin alone supplied Lagos with 800 puncheons of oil every week. ${ }^{22}$

\section{Organisation of trade and market activities in Ejinrin}

The Ejinrin market was connected with the hinterland by a network of creeks and rivers. This is because the lagoon on which the market was located made in-land navigation possible. For instance, the Yemoji River linked Ijebu people to Ejinrin. People from Ito-ikin, Aiyepe, Odobgolu and Remo towns also travelled to Ejinrin on the Ona River. The Osun River connected the people of Ijebu-Igbo and environs to Ejinrin. Canoes from these places disembarked at the same point in Ejinrin port.

European countries therefore, made the trade more lucrative as the unit price of a slave rose making smuggling an attractive business. Smith, Lagos Consulate, 21.

18. Babafemi Ogundana, "Lagos: Nigeria’s Premier Port" Nigerian Geographical Journal, 4.2 (1961): 26.

19. Michael Crowder, The Story of Nigeria (London: Faber and Faber, 1966), 126.

20. A. A. Lawal, "Trade and Finance of the Lagos Colony, 1861-1906" in Ade Adefuye, et al., History of the Peoples of Lagos State (Lagos: Lantern Books, 1987), 65.

21. O.O Ayantuga, "Ijebu and its Neighbours, 1851-1914" (Ph.D Thesis, University of London), 90.

22. Ibid., 88 . 
Ejinrin market was held every eight days. The arrangement was such that traders had the opportunity to attend other lagoon markets at Atijere, Ikosi, and Ikorodu. Trading activities in Ejinrin usually spread over three consecutive days. The first market day was known as Adeele and by the evening of that day, traders from different locations would have arrived in Ejinrin. No trading was done on this day. The following day was called Aworo. Trading took place on this day from morning till late in the evening. If business was not completed, it continued the third day. On this third day, trading activities ended and traders departed for their homes.

Transportation of goods in Ejinrin was done by canoes. Transportation to the market by overland route was essentially by human porterage. For the latter, professional carriers as well as slaves were used. For water transportation, the dug-out canoes were used; the carriage capacity of canoes varied from two to eighty persons, or from 2 to 16 puncheons of oil. ${ }^{23}$ These means of transportation were generally efficient though they had their limitations.

Ejinrin market was connected by three major trade routes. The first was the northern route that came into existence in the nineteenth century. His was the Ibadan-Ijebu Ode- Ejinrin route. The second route was the south-eastern route otherwise referred to as Atijere route. The route which developed in the nineteenth century linked the Ekiti and Ondo people to Ejinrin. The third route was the south-western route which linked Lagos, Ijede, Lekki and Orimedu to Ejinrin. In the same manner, European goods reached Ejinrin market from Lagos through the port. From Ejinrin, articles brought from the northern route passed through to Lagos and similarly, European goods reached Ejinrin market from Lagos via the market.

In the market, European articles such as gun, ammunition, gin, rum and tobacco were bartered for hinterland produce such as palm nut and palm oil. It is necessary to stress that each of the trade routes mentioned was important for particular articles of trade at certain periods. For instance, the Atijere route was important for palm oil. ${ }^{24}$ From Atijere, palm oil came to Ejinrin and through the port it was shipped to Lagos. The inhabitants of Ejinrin did not produce palm oil, implying that the bulk of the palm oil that got to Ejinrin market probably came through this route. Fish also came to Ejinrin through the Atijere route. The Ibadan-Ijebu Ode Ejinrin route was particularly import-

23. See, Sir Alfred Moloney "Notes on Yoruba and the Colony and the Protectorate of Lagos, West Africa" Proceedings of the Royal Geographical Society (1890): 608; For further discussion of the use and importance of canoe, see Robert Smith, "The canoe in West Africa History" Journal of African History, XI (1970), 515-533.

24. Chief S. B. Akintola, interviews cited; and Mr. Oyakeye, 45 years interviewed at Ejinrin on 26th April, 1988. 
ant for the supply of slaves. Other items which came through the route included palm oil, palm kernels, yam, woven cloth, maize and beans. ${ }^{25}$ However, the importance of this route was undermined by the frequent closure of the Ijebu route during the nineteenth century Yoruba civil wars.

Tolls were collected at the entry point to the market. ${ }^{26}$ This was on the Ibadan-Ijebu Ode-Ejinrin route. No toll was collected on the water route. Tolls were imposed by the Awujale who stationed his Agunren (toll collector) at the terminal point on the trade route. Traders passing through the trade route to the market paid to the toll collector in cash, ${ }^{27}$ (probably in cowries). Traders who could not pay in cash did so in kind.

The activities of the middlemen and women otherwise called the alarobo and amugbalegbe represented an important feature of trading activities in Ejinrin market. Alarobo and amugbalegbe were confined to the fish and palm oil trade. ${ }^{28}$ The exact reason for this is not known but it could be that these were the two trading activities that attracted many buyers and sellers to Ejinrin. In the fish trade, the Alarobo were predominantly women while in the palm oil trade, they were men. Membership was open to any trader. But once a trader joined, he automatically became a member of the Alarobo association. The association was headed by an Iya Egbe (President) in the case of the fish trader and in the palm oil trade, he was known as Baba-Egbe (President).

When canoes arrived in the port with consignments of fish, the Alarobo usually met directly with the traders who had brought them. They purchased fish from the traders (mostly Ilaje people) and sold to traders from different parts of Yorubaland..$^{29}$ Since traders from the hinterland had no stalls, they stayed in the ones owned by the alarobo. Consequently, a practice developed whereby it became virtually impossible for the hinterland traders to bypass the alarobo. For the performance of their roles as middlemen or women, the alarobo collected 4 shillings on every E1 ( 2 2) of fish sold. ${ }^{30}$

In the palm oil trade, the amugbalegbe functioned as middlemen. Traders from the hinterland could not sell directly to those from Lagos. This was usually done through the amugbalegbe. Thus, when palm oil traders arrived in

25. Later in the twentieth century cocoa, rubber and timber came through this route to Ejinrin.

26. Chief S. B. Akintola, interviews cited. Informants could not give the specific amount collected on articles of trade.

27. Chief S. B. Akintola, interviews cited.

28. Madam Ibidunke (Iya Kayode), c. 97 years, interviewed at Ejinrin.

29. Three Alarobo interviewed at Ejinrin market on 26 April, 1988. They were Madam Silifatu Basorun, 63 years, Mrs. Idayatu Matesi, 61 years and Mrs. Isikatu Basorun, 59 years.

30. Madam Sala, C. 70 years interviewed at Oke Aje market in Ijebu-Ode on 27th April, 1988. 
Ejinrin from the hinterland, they entrusted their goods to the amugbalegbe who sold the produce to traders from Lagos. For their role, the middlemen collected a fixed commission depending on the quality of the palm oil. ${ }^{31}$ This middleman system involved financial risks. Although the arrangement was based on trust, it was often violated. For instance, traders sometimes collected fish or European goods on credit with a promise to pay the next market day; but sometimes that trader might fail to pay as promised. In spite of this, the system appears to have been effective in meeting the needs of buyers and sellers. Thus, it survived till the twentieth century.

The Pampa (market officials) supervised the entire administration. ${ }^{32}$ They ensured that market activities were done in an orderly and peaceful manner. They also saw to the safety of goods and property in the market. They were always in the market on market days. Members could be up to twelve or more and membership was not confined to the indigenes of Ejinrin alone. Any trader found to be credible and trustworthy in character was appointed member of the Pampa. They were appointed by the political authority, presumably the Awujale of Ijebu-Ode. Pampa members did not receive any fixed stipend. But any trader who wished, gave them commodities such as yam and maize. This was done in appreciation of their role in the market. ${ }^{33}$

The medium of communication in Ejinrin market was the Yoruba language. Even though non-Yoruba speakers attended the market, they were often able to understand Yoruba language. This was the result of cultural contact and interaction over the years. However, when a particular trader could not converse in Yoruba language, the service of an interpreter was engaged. ${ }^{34}$

Currency as a means of exchange is an important aspect of market transactions. In Ejinrin market, different currencies were used at certain periods. One of the earliest means of transaction in the market was the barter trade. Palm oil and slaves were bartered for European goods such as spirits, guns and ammunition. Also cowries (cypraea moneta) were used in the market. Cowries gained general acceptability throughout Yorubaland during the nineteenth century. ${ }^{35}$ From the coast, their use spread inland through the main arteries of trade. ${ }^{36}$ Evidently in 1860 , the Ijebu and Ibadan traded in

31. Chief S.B. Akintola, interview cited earlier.

32. Madam Ibidunke and Chief Akintola, interviews cited. See also, B.W. Hodder, "Markets in Yorubaland" (Ph.D Thesis, London, 1963), 93.

33. Chief S.B. Akintola, interview cited earlier.

34. Mrs. Moriamo Gbadamosi, interview cited earlier.

35. Ogunremi, Counting the Camels, 42.

36. Marion Johnson, “The Cowrie Currencies of West Africa, I" Journal of African History, XI. 1, (1970), 35. 
cowries. ${ }^{37}$ The cowrie was acceptable as medium of exchange because its size and shape made it easy to handle and convenient to count. It was also impossible of being counterfeited. ${ }^{38}$

Apart from the cowrie, Spanish or South American dollars were used as currency in Ejinrin market. ${ }^{39}$ They were introduced by the slave traders. Dollars became established as the most important currency after the cowrie. ${ }^{40} \mathrm{Ex}$ change rate of dollar in April 1860 was 4s. 6d per dollar, and 4s. 6d. per 5,000 cowries or two heads and half of cowries. ${ }^{441}$ But throughout the nineteenth century the dollar was unstable as its exchange rate was irregular. However, dollars were useful for large transactions for which the cumbersome cowrie was least suited and wee advantageous in that they received ready acceptance for business transactions by the European and Brazilian merchants who put them into circulation. ${ }^{42}$

By the end of 1880 , there was a fall in the value of cowries. The fall in value was attributed to over-issue, i.e. inflation. Consequently, British silver was introduced and was accordingly used in Ejinrin market. ${ }^{43}$ But this new currency was detested by Ijebu traders partly because of the difficulties encountered in adjusting the rates of exchange to suit it. The Awujale in 1887 protested against the introduction of the silver coins in Ijebu markets but this received no response as he was told that "there is little point in trying to resist the inevitable". ${ }^{44}$ By 1890, it was still difficult to adjust the rates of exchange to suit the new currency. As a result, the cowrie continued to be used, albeit on a limited scale, in small-scale transactions. The usage of the cowrie continued until early in the twentieth century when it finally disappeared from the main centers of trade.

\section{Trade during the colonial dispensation, 1892-1939}

In Ijebuland, the colonial period began with a British military expedition against the Ijebu in 1892. This episode is referred to in history as the An-

37. English Appendix to The Iwe Irohin, 24th March, 1860, unpaged.

38. A.G. Hopkins, "The Currency Revolution in South-West Nigeria in the Nineteenth Century" Journal of the Historical Society of Nigeria, Vol, III, No. 3, Dec., 1966, 472.

39. A.G. Hopkins, "The Currency Revolution" (1966), 473. This was confirmed by Madam Asepita Mojibade, C.90 years, interviewed at Irolu-Remo on 30th April, 1988 and Madam Saliatu, 100+ years, Iyalode of Agbowa interviewed on 28th April, 1988.

40. A.G. Hopkins, "The Currency Revolution", 473.

41. English Appendix to The Iwe Irohin, April 1860.

42. Hopkins, "The Currency Revolution", 473.

43. Ibid., p. 482; Madam Asepita Mojibade, C, 90 years, interview cited.

44. Hopkins, "The Currency Revolution", 482. 
glo-Ijebu war of 1892 or the Ijebu Expedition. The Ijebu Expedition had far-reaching implications for trade both in the Yoruba hinterland and on the Lagos Lagoon on which Ejinrin market was located. The Expedition led to the immediate opening of Ijebu trade routes to everyone, and for the first time, traders from the hinterland moved freely to Ejinrin market. This increased the volume of trade in the market. Indeed, four months after the Expedition (in September 1892), a large number of upland commodities were found in the market. These included foodstuffs such as beans, farina, groundnuts, locust seed, maize, okro, palm oil, pepper, shea butter, yams and yam flour. Raw materials in the market included cotton, indigo, palm kernels and potash. Among the livestock found were bullocks, ducks, goats, guinea fowl, horses, pigeons, sheep and turkeys. Manufactured items included calabashes, cotton cloth, pots, soap and yarn. Of these items, palm oil and palm kernels were important in the overseas trade. ${ }^{45}$

The conditions engendered by the Expedition created a conducive atmosphere for commercial transactions in Ejinrin. For instance, the trade routes became free, making it possible for more people from the interior to attend Ejinrin market. Consequently traders came from Ile Ife, Gbongan, Ilesha, Oyo, Ilorin, Ado-Ekiti and Owo. The Ijo and Ilaje also moved in increasing number to fish in Ejinrin. ${ }^{46}$ The effect of this was that attendance at Ejinrin market increased tremendously. In 1895, between 20,000 and 26,000 persons were present at Ejinrin on each market day ${ }^{47}$ and by 1908 , the market was described as "the largest market in [the] Western Provinces of Southern Nigeria". ${ }^{4}$ This description emanated from the high volume and value of trade at the market at this time.

The Ijebu Expedition also put a final end to the trade in slaves in Ejinrin market. As late as October 1882, slaves were still being taken from Ejinrin port to Lagos. ${ }^{49}$ This was in spite of the fact that the British had officially abolished the overseas slave trade since early in the nineteenth century. But the Ijebu Expedition struck a severe blow to the slave trade. This was due to the presence

45. C.O. 137/86, Carter to Ripon, 4 October 1892, Public Record Office, as cited in A.G. Hopkins, Economic History of West Africa (Longman, 1973), 55.

46. T.O. Avoseh, A Short History of Epe (Epe: St. Michael's Anglican Church, n. d.), 17.

47. National Archives Ibadan [NAI] CSO 1/1 15 Despatches to Secretary of State Nos. 1 to 246.2 nd Jan. -31 st Dec. $1895,110$.

48. C.O. 520/74: Report on the Western Province of Southern Nigeria - E. P. Cotton, 19th Feb., 1902, As cited in O.O. Ayantuga, "Ijebu and its Neighbours, 1851 - 1914" (Ph.D Thesis, University of London, 1965), 322.

49. The African Times, 2nd October, 1882, 112; Although the European countries had stopped the slave trade, African slaves were being demanded and used in countries like Turkey, Egypt and Persia. See The African Times, 1st Sept., 1879. 
of European officers in command of detachments of Hausas soldiers stationed at Ijebu-Ode who ensured that peaceable traders were not molested on their way to the lagoon markets, and that no trade in slave was undertaken. ${ }^{50}$

The formal establishment of colonial rule over Ijebuland ushered in a number of changes in Ejinrin. We have already noted that after the Expedition, peace was established over Ijebuland. This created a conducive atmosphere necessary for trade to flourish. Consequently, trade in Ejinrin market increased both in the volume and value. The level of commercial activities in the market was so high that in April 1896, the British District Commissioner considered it necessary to open a new market at Itoikin in order to ease congestion in Ejinrin market. ${ }^{51}$

The establishment of British administrative control over Ijebuland ushered in a system of road network development in the area. The roads were designed to link the major producing areas with the lagoon markets. Ejinrin was one of the most important of such markets. By 1900, a road had been constructed from Ejinrin to Ijebu-Ode. Another was built from Ijebu Ode to Epe. ${ }^{52}$ The road from Ijebu Ode was extended to Ijebu-Igbo and by 1939 it got to Ibadan. The immediate effect was that Ibadan and Ijebu-Igbo areas which were rich in the production of cocoa now transported their produce to Ejinrin with ease.

Another important change which accompanied the inauguration of colonial rule in Ijebuland was the generalization of the use of currency. Although cowries had served as an important medium of exchange since the nineteenth century, by the early twentieth century they had declined in importance. In 1908 , the penny and the tenth of a penny pieces were introduced. ${ }^{53}$ This currency became an effective medium of exchange. It acted as a standard of value and a store of wealth. Agricultural produce came to enjoy a wider range of acceptability than hitherto in the market. Furthermore in 1936, Bank of England notes were introduced in large quantity. ${ }^{54}$ Unlike the cowries of the nineteenth century, the wide acceptance of an all-purpose money in the twentieth century made all commodities expressible in terms of a single-standard and hence, immediately exchangeable. ${ }^{55}$ This development contributed to the growth of trade and enhanced the prosperity of trade in the lagoon markets.

Another noticeable development which accompanied the establishment of colonial rule in Ijebuland was the movement of European trading companies

50. N.A.I. CSO1/1 14 Lagos Dispatches to Secretary of State, 18th December, 1894, 236-237.

51. N.A.I. CSO 1/1 16 Dispatches to Secretary of State 17th January, 1895: 293.

52. N.A.I.: Epe Div. 7/2 Epe: Intelligence Record Book, 1900-17, 18.

53. Kirk Greene, 148.

54. N.A.I.: CSO 26/4/09512, Vol. XI Colony Annual Report,1936, 480.

55. B. W. Hodder, "Markets in Yorubalaand" (Ph.D Thesis, London, 1963), 80. 
from the coast to Ejinrin market. ${ }^{56}$ European companies were probably attracted to Ejinrin because of the boom in trade between 1917 and 1919. The movement to Ejinrin market was also motivated by the desire to build up a virile and stable trade in the export of cash crops. One of such was African Oil Nuts Company which settled there in 1921, followed by the Hamburg Nigeria Company and G. B. Ollivant in 1926. Later in the year, both started to build stores in the lagoon market.

In Ejinrin, these trading firms purchased cocoa and palm kernels. They used their stores and warehouses for sifting, bagging and weighing the produce before taking the goods to the port for shipment. It should be stressed that these firms purchased produce through their agents who were mainly indigenes. The agents acted as middlemen between the hinterland producers and the Europeans. For import trade, there was an arrangement by which indigenous traders collected goods from the Europeans after signing the necessary papers with a promise to pay after selling the imported goods. Goods purchased in the lagoon market were taken as far as the northern part of Nigeria.

Colonial rule revolutionized the water transportation system on the lagoon. Traditional means of communication based on rafts and dug-out canoes were replaced by motor boats. The dug-out canoes were slow, often taking almost a day's journey from Ejinrin to Lagos. What was more, the canoes were often disturbed by gales or storms. This sometimes resulted in mishaps in which many lives and property were lost. In 1919, Mr. Joshua Ricketts, the fourth son of Reverend John Edwards Ricketts of the Agbowa Enterprise went into boat building. ${ }^{57}$ By 1921 he had built the first motor launch which he christened "Letitia", after his mother. This motor launch plied the important lagoon markets of Ejinrin, Epe, Ikorodu and Atijere connecting them to Lagos. The motor launch carried up to twenty-five passengers and moving at a speed of eight miles (12.9 kilometers) per hour, covered the distance between Lagos and Ikorodu in one and a half hours. ${ }^{58}$ The service was, therefore, a marked improvement in ensuring speed and safety in water transportation on the lagoon.

The increase in commercial activities along the lagoon provided job opportunities for people of diverse origins. Many people moved to Ejinrin to work either as clerks or shopkeepers in the European firms or as laborers in the port

56. See, N.A.I.: CSO 26/23631 Intelligence Report-Epe District, Lagos Colony, 73 and N.A.I.: CSO 26/4/09152 Colony Annual Report, vol. IV 1927, 98.

57. For details of the activities of the Ricketts in the Colony of Lagos, see Ade Adefuye "John, Gershion and Joshua Ricketts: Jamaican Contribution to the Socio-Economic Transformation of Colony Province" in G. O. Olusanya, ed., Studies in Yoruba History and Culture (Ibadan: University Press, 1983).

58. B.A. Agiri, "Lagos-Ikorodu Relations, 1894-1950" in Ade Adefuye et al., History of the Peoples of Lagos State (Lagos: Lantern Books, 1987), 211. 
of trade. ${ }^{59}$ Some people also settled there permanently for trading purposes. A number of Isoko, Urhobo and Ukwuani speakers from the Delta province migrated to the area. They worked mainly as laborers in the port but did some farming, mainly in oil palm cultivation. Igbirra and Hausa speakers also moved to Ejinrin as cattle and kola nut traders. From the Western Delta, Ilaje came to take advantage of fishing opportunity that existed in the Ejinrin lagoon. ${ }^{60}$ Consequently, the overall population of Ejinrin and indeed the whole of Epe Division increased from 20,000 in 1900 to 34,030 in $1921 .{ }^{61}$ The increase in population was partly due to the "pull" factor of Ejinrin and Epe which attracted people to the Division.

\section{Conclusion}

By 1939 which is the end of the period covered in this article, Ejinrin had evidently grown to become an international market. Several European trading firms could be seen operating in the market engaging in export produce trade and bringing in imported goods for sale to indigenous traders who distributed these items to markets in the hinterland. Lack of statistical data will not allow us to show the actual volume and value of trade in the market but the trends were obvious enough to enable one conclude that Ejinrin had become a major center of commercial activities along the stretch of the Lagos Lagoon. The market had become not just a place where traders and sellers met but had also developed into a community where people from different parts of Nigeria came to settle.

It is instructive that in all, the Nigerian traders demonstrated ingenuity, commercial acumen and great ability for adaptation in the face of the many challenges posed by colonial rule and the international trade that took place in the market. The commercial prosperity of Ejinrin and indeed, the stretch of the Lagos Lagoon continued beyond the Second World War period. Indeed, the market did not begin to experience a decline until the middle of the twentieth century but the discussion of the dwindling fortunes of the market is outside the scope of this article.

59. Ade Adefuye, "Lagos Communities of Epe Division: Melting Pots of Culture" Journal of Business and Social Studies (N.S.) Vol. No. 2, (June, 1980), 154.

60. H. I. Ajaegbu, "Recent Migrations and Settlement in the Coastal Areas of South West Nigeria: The Example of Epe and Ikeja Divisions" Nigerian Geographical Journal, II (1968), 70-73.

61. Ibid. 